\title{
A GLACIAL TRACK IN THE PEAK DISTRICT OF DERBYSHIRE versus THE POTLUCK SILL.
}

Sir,--In the Geologrcal Magazine for February, 1935, on page 96, is a letter from Mr. Philip Jessop, in which he says that the boulders of dolerite and the outcrop of lava "led Bemrose (Q.J.G.S., $1907,241)$ to infer the existence of an intrusive sill at this place. Detailed examination shows, however, that the boulders are not in situ".

Mr. Jessop postulates that the boulders have been transferred to their present locality by ice.

I have lately made several visits to Potluck. During the last year or two, a number of trial holes and several bore-holes have been made in at least three fields. The holes made near to where the boulders are on the ground, prove that the rock is in situ. I have examined thin slices made from three specimens taken from two of the bore-holes. One of them was drilled to a depth of $115 \mathrm{ft}$., and another to $70 \mathrm{ft}$., without getting through the intrusive rock. Two specimens from the first hole at depths of $106 \mathrm{ft}$. and $115 \mathrm{ft}$. respectively, consist of ophitic olivine-dolerite. From the second hole the specimen from a depth of $70 \mathrm{ft}$. is an olivine-dolerite with granular augite. They are very similar to the rocks I collected more than thirty years ago, but the olivine is in a much fresher condition. The bore-holes are about 150 yards from Black Hillock shaft.

We therefore have proof that here the sill is at least $115 \mathrm{ft}$. thick. These facts fully justify my having mapped this rock as a sill.

218 Osmaston Road,

H. H. Bemrose.

DERBY.

20th July, 1937.

\section{GEOLOGY OF ECUADOR.}

SIR,-I have read with much interest Dr. George Sheppard's recent book The Geology of South-Western Ecuador, and, in so far as many of the results originally appeared in the pages of this Magazine, the following remarks may prove of interest to your readers. During several months work in South-Western Ecuador the writer had occasion to make preliminary reports (in note form) on specimens, etc., collected in the area described by Dr. Sheppard. A number of these observations have been included in the book (see pp. 72-74, 136-138) and it is felt that in order that due allowance shall be made for possible inaccuracies, attention should be called to the fact that these remarks were not prepared for publication, and indeed their inclusion came as somewhat of a surprise to the writer. 
The palaeontological identifications were made without specialized knowledge of Tertiary mollusca and without the advantage of literature other than the standard textbooks on palaeontology. As an example may be quoted the reference to the echinoid cf. Coelopleurus sp. (see Sheppard, p. 137) which the writer later found in the Quaternary and living, and identified as Arbacia incisa (A. Agassiz) with the help of Mr. A. G. Brighton (see Barker, Geol. MaG., 1933, LXX, p. 89). The references to sedimentation contained on pages $72-4$ contain ideas which have since been modified to some extent by the writer, and were based on a very superficial knowledge of Ecuadorian geology, and for this reason may be open to criticism.

The fauna of the Tablazos was treated in a brief note in 1933 (R. W. Barker, GEoL. MAG, LXX, 84-90), to which no reference is made by Dr. Sheppard, and the species referred to as Bulimus sp. (p. 146) was identified as Porphyrobaphe iostoma (Sowerby), a species still common in the Colonche area. The echinoid referred to as Mellita was identified (with the help of Mr. A. G. Brighton) as Encope micropora L. Agassiz and considerable changes made in earlier identifications (in MS.) of Tablazo molluscan species.

Additional points, perhaps worthy of mention, are firstly the absence of any reference in the stratigraphy to the beds exposed at San Pedro (see Barker, Geol. MAG., 1932, LXIX, 277-281), and secondly the discrepancy between the correlation given by Sheppard (p. 105) and by Vaughan (pp. 154, 157). As a result of the first, Dr. Vaughan concludes that beds of Middle and Upper Oligocene and Lower Miocene are present at San Pedro (see p. 158), whereas only a single faunal assemblage exists, the three species, Nephrolepidina sp. cf. verbeeki Newton and Holland, Miogypsina panamensis (Cushman), and Miogypsina cushmani Vaughan occurring in association at a single horizon. Vaughan also refers to the absence of the San Pedro beds from Dr. Sheppard's section.

With respect to the second point, on page 105 Sheppard refers to the Guayaquil Limestone as probably Upper Eocene (on evidence published by Vaughan in 1930), ignoring evidence given by the writer in 1932 (Barker, Geol. MaG., LXIX, 302-303) and by Vaughan on p. 157 of Sheppard's book, which gives a "Lower or Middle Eocene, more probably Middle Eocene "age to the beds. As a result Sheppard is in favour of correlating the Guayaquil Limestone with the Upper Eocene Seca Shales, whereas Vaughan suggests correlation (on much more reliable evidence) with the Middle Grits (Lower or Middle Eocene, probably the latter). The writer is not in entire agreement with Dr. Vaughan in respect to the identification of the species of Discocyclina from the Guayaquil Limestone, but as this requires further research it must be deferred to a later date. No reference is made in the correlation to a paper by Todd and the writer (GEOL. MAG., 1932, LXIX, 529-543) in which a succession is given for the Peruvian Tertiary, with information regarding the distribution of larger foraminifera, which, it is felt, might have proved of value 
in connection with the later work of Dr. Vaughan in comparing the Ecuadorian section with that exposed in North-Western Peru. It is to be hoped that at some future date material may be available for the detailed correlation of this part of the world by means of smaller and larger foraminifera, but until this is possible the lithological studies of Dr. Bosworth and Dr. Sheppard will continue to be the standard works of reference.

Tampico, Mexico.

R. Wright Barker. 27 th $J u l y, 1937$.

\section{SPRING PITS AND SANDSTONE PIPES.}

Sir,--The recent account by Dr. R. W. Pocock (Abstract Proc. Geol. Soc., 1937, p. 126) is of interest to me because these Cambrian pits remind me of the Sandstone Pipes in Carboniferous Limestone, described in the Anglesey Memoir, pp. 612-16 (also 631-2, 635-6), and shown in plates xxxviii, xxxix. The Carboniferous pipes, however, attain to considerably greater dimensions.

They have been found on five horizons, from the base of $D_{2}$ to nearly the summit of $\mathrm{D}_{2} b$, a thickness of some 700 feet. But they resemble the Cambrian pits in that, on none of these horizons are they likely to have been far from a coast.

On pp. 615-16 I discussed their probable causes, favouring (though with misgivings) the seismic theory of Professor Hobbs. The idea of such pits having been drilled by water from below is common to his suggestion and to that of Dr. Pocock. The new evidence seems to postulate only ordinary springs, so perhaps, in view of it, we can dispense with earthquakes. Yet the size of the Carboniferous pipes seems to require uncommon vigour in the springs that drilled them out.

Edward Greenty.

BANGOR.

July, 1937. 